SAINS TANAH - Journal of Soil Science and Agroclimatology

Journal homepage: http://jurnal.uns.ac.id/tanah

\title{
Carbon dioxide emission and peat hydrophobicity in tidal peatlands
}

\author{
Siti Nurzakiah*, Nur Wakhid, Anna Hairani \\ Indonesian Swampland Agriculture Research Institute, Jl. Kebun Karet, Loktabat Utara, Banjarbaru, South Kalimantan, \\ Indonesia
}

\begin{tabular}{|c|c|}
\hline ARTICLE INFO & ABSTRACT \\
\hline $\begin{array}{l}\text { Keywords: } \\
\text { Functional groups of peat } \\
\text { Land use } \\
\text { Soil water content } \\
\text { Article history } \\
\text { Submitted: 2020-04-14 } \\
\text { Accepted: 2020-06-24 } \\
\text { * Corresponding Author } \\
\text { Email address: } \\
\text { sitinurzakiah1@gmail.com }\end{array}$ & $\begin{array}{l}\text { Peatland describes the typology of tidal and freshwater swamplands. Peatlands are } \\
\text { affected by tidal activity; the water level fluctuation causes the peat to dry out and then } \\
\text { get wet, which affects the soil's water content and carbon emissions. Additionally, mineral } \\
\text { enrichment from river overflows affects soil fertility and peat stability. Peat stability is } \\
\text { importantly related to the peatland management for agriculture. Functional groups in the } \\
\text { peat, such as carboxyl and hydroxyl, are volatile and easily transform, decomposing from } \\
\mathrm{CHO} \text { bonds into } \mathrm{CO}_{2} \text { under aerobic conditions. The characteristics of functional groups can } \\
\text { be changed from polar to non-polar at the organic colloid surface, leading to } \\
\text { hydrophobicity. This study evaluated carbon dioxide emissions and peat hydrophobicity. } \\
\text { The research was conducted by survey and field sampling on two differently managed plots } \\
\text { of peatlands: a rubber-and-pineapple intercrop plot and a traditionally-managed rubber } \\
\text { plot. Parameters measured were } \mathrm{CO}_{2} \text { flux, groundwater levels, water content, and peat } \\
\text { hydrophobicity. Peat hydrophobicity was assessed by analyzing certain functional groups } \\
\text { using a Fourier-Transform Infrared (FTIR) spectrophotometer. The results showed that CO } \\
\text { emissions were } 21.78 \pm 5.44 \text { (mg ha }{ }^{-1} \mathrm{yr}^{-1} \text { ) for the rubber-and-pineapple intercrop and } \\
19.15 \pm 5.18\left(\mathrm{mg} \text { ha }{ }^{-1} \mathrm{yr}^{-1}\right) \text { for the traditionally-managed rubber plot. Peat hydrophobicity } \\
\text { for both plots decreased with increasing soil depth, indicating that peat on the surface } \\
\text { layer }(0-50 \mathrm{~cm}) \text { is more vulnerable to drought and fires, especially if there is no water } \\
\text { management. }\end{array}$ \\
\hline
\end{tabular}

How to Cite: Nurzakiah, S., Wakhid, N., and Hairani, A. (2020). Carbon dioxide emission and peat hydrophobicity in tidal peatlands. Sains Tanah Journal of Soil Science and Agroclimatology, 17(1): 71-77 (doi: 10.20961/stjssa.v17i1.41153)

\section{Introduction}

Indonesia has the world's largest area of tropical peatlands (Rieley \& Page, 2016), about 13.4 million ha (ICALRRD, 2019), mainly located in Sumatra, Kalimantan, and Papua; thus, peatlands should be considered for their potential as agricultural or plantation areas. However, there are several problems when peatlands are used for agriculture, including low soil fertility; furthermore, peatland-clearing activities, such as drainage development, can result in subsidence and fire risks that have the potential to increase carbon emissions, especially $\mathrm{CO}_{2}$. Therefore, peatlands need to be used carefully and adapted for their potential by applying the appropriate land management technologies.

Tropical peatlands have diverse soil properties, both spatially and vertically. They are strongly influenced by the environmental conditions that created them, including enrichment, or lack thereof, from the surrounding river's overflow, which affects soil fertility and peat stability. The main factor affecting peat stability is the peat's inherent nature (Sollins et al., 1996), which is determined by the role of functional groups $-\mathrm{COOH},-\mathrm{C}=\mathrm{O},-\mathrm{C}-\mathrm{OH}$, and phenol- $\mathrm{OH}$, which form the active substance of organic colloid, and organic acid derivatives resulting from the process of organic matter decomposition. Organic acid derivatives are the primary form of $\mathrm{C}$ release from the oxidation process of the carboxyl and methoxy functional groups. Thus, peat can release $\mathrm{CO}_{2}$ into the atmosphere.

Carbon from the atmosphere is sequestered in the soil organically through vegetation deposits and accumulation of recalcitrant organic matter and inorganically by bicarbonate weathering of the silicate mineral in a parent material (Chadwick et al., 1994). Soil carbon stocks are strongly influenced by peat thickness, ash content, and land area. The amount of carbon emissions varies according to peat thickness, degree of peat decomposition, and peat hydrological conditions, as well as vegetation factors such as species and varieties and their stages of growth (Agus et al., 
2013; Glatzel et al., 2004; Hooijer et al., 2010; Melling \& Hensen, 2011). If peatlands are turned into agricultural land, it will cause changes to the physical, chemical, and biological properties of the soil, including the volume of peat shrinking when the area is drained, which will increase oxygen availability and potentially increase decomposition. Oxygen input is also an essential factor for the renewal of inorganic electron acceptors with the potential to suppress methanogenesis (Knorr et al., 2009) and for the activation and deactivation of the exo-enzymes that control peat decomposition (Freeman et al., 2001).

Peat decomposition is related to microbial activity, nutrient availability, and environmental factors such as temperature and soil moisture (Hoyos-santillan et al., 2016; Laiho, 2006; Moyano et al., 2013). Soil moisture in the upper layer can be a better predictor of $\mathrm{CO}_{2}$ production than groundwater level (Melling et al., 2013; Moyano et al., 2013) because soil moisture is a result of capillaries rather than groundwater level (Michel et al., 2001; Moyano et al., 2013). While groundwater-level fluctuations affect the availability of soil oxygen, the level of groundwater cannot be used as an indicator of soil moisture, which affects the $\mathrm{CO}_{2}$ emissions on peatlands.

An inherent factor for peat moisture is the degree of peat decomposition associated with soil pores. Peat pores are very complex, with different physical and hydraulic characteristics. Peat has a very irregular and interconnected macropore (Rezanezhad et al., 2010), and there are also open and closed micropores (Hoag \& Price, 1997). Undecomposed peat pores exceed $5 \mathrm{~mm}$ (Rezanezhad et al., 2016), but they significantly reduce size during drying, compression, and decomposition. When the land is drained, peat volume shrinks due to the loss or reduction of peat water content. If the decreased water content gets below the critical water-content level, the peat becomes hydrophobic. The critical value of peat water content varies depending on the peat's characteristics but ranges between 216.9-417.8\% (Azri, 1999), 55-73\% (Masganti. et al., 2001), and 151.4-169.4\% (Winarna, 2015).

Hydrophobic describes a condition where peat can no longer absorb water or irreversible dries. Irreversible drying is determined by peat hydrophobicity, a qualitative, or semiquantitative, parameter that describes the level of interaction between surface water and soil particles. According to Valat et al. (1991), peat hydrophobicity is caused by 1) humic acid covered with wax, which is naturally hydrophobic; 2) the presence of non-polar groups such as ethyl, methyl and aromatic compounds, which are hydrophobic, and a simultaneous reduction in the number of hydrophilic groups; 3) absorption of hydrophobic compounds such as oil, fat, and organic-fractions on the surface of the humate fraction. Therefore, reduced peat water content does not directly change the peat from hydrophilic to hydrophobic, but triggers peat to become drier and more susceptible to fire. Burning peat contributes to global warming by releasing $\mathrm{CO}_{2}$ into the atmosphere. Hence, water management is critical for peatlands, leading this study to evaluate carbon dioxide emissions and peat hydrophobicity for two different land-use systems.

\section{Materials and Method}

The research was conducted on two different plots of peatlands in Pulang Pisau District, Central Kalimantan Province (location: $02^{\circ} 24^{\prime} 28^{\prime \prime} \mathrm{S}, 113^{\circ} 38^{\prime} 42^{\prime \prime E}$ ); one was a rubber and pineapple intercrop (IRP), and the other was traditionally managed rubber (TMR). The research used a survey method followed by field sampling of soil and gas. Peat thickness ranged from 481 to $600 \mathrm{~cm}$ for the IRP and 93 to $582 \mathrm{~cm}$ for the TMR; the degree of peat decomposition for both land-uses was predominately sapric. Soil and $\mathrm{CO}_{2}$ sampling and groundwater-level observations were carried out between January and December 2015.

\subsection{Measurement of $\mathrm{CO}_{2}$ fluxes and groundwater level}

The sampling of $\mathrm{CO}_{2}$ was conducted between 6 and 8 am. The gas chambers were block-shaped, made of polycarbonate material (length: $50 \mathrm{~cm}$; width: $15 \mathrm{~cm}$; height: $30 \mathrm{~cm}$ ), and installed at distances of $16 \mathrm{~m}, 100 \mathrm{~m}$, and $200 \mathrm{~m}$ from the drainage channel. A gas sample was taken using a syringe with a capacity of $10 \mathrm{~mL}$. Gas was sampled at five-minute intervals: $5,10,15,20$, and 25 minutes. The sample was then analyzed using a micro GC, type 4900, with a Thermal Conductivity Detector. Measurement of $\mathrm{CO}_{2}$ fluxes was carried out using the closed-chamber technique adopted from the IAEA (IAEA, 1992). The calculation of fluxes at each observation point was performed using the following equation:

$$
E=\frac{B m}{V m} \times \frac{\delta C s p}{\delta t} \times \frac{V}{A} \times \frac{273.2}{T+273.2}
$$

where:

$\mathrm{E}=\mathrm{CO}_{2}$ emissions $\left(\mathrm{mg} \mathrm{m}^{-2}\right.$ minute $\left.^{-1}\right)$

$\mathrm{V}=$ chamber volume $\left(\mathrm{m}^{3}\right)$

$A=$ width of chamber base $\left(\mathrm{m}^{2}\right)$

$\mathrm{T}=$ average temperature inside the chamber $\left({ }^{\circ} \mathrm{C}\right)$

$\delta \mathrm{Csp} / \delta \mathrm{t}=$ change rate of concentrations of $\mathrm{CO}_{2}$ gases $(\mathrm{ppm}$ minute ${ }^{-1}$ )

$\mathrm{Bm}=$ molecular weight of $\mathrm{CO}_{2}$ gases in a standard condition $\mathrm{Vm}=$ gas volume at standard temperature and pressure; i.e., 22.41 liters at $23^{\circ} \mathrm{K}$

Groundwater-level measurements used wells made from PVC pipes with diameters of $3.8 \mathrm{~cm}$ and lengths of $200 \mathrm{~cm}$. The PVC pipes were installed at distances of $16 \mathrm{~m}, 24 \mathrm{~m}, 32 \mathrm{~m}$, $40 \mathrm{~m}, 100 \mathrm{~m}, 150 \mathrm{~m}$, and $200 \mathrm{~m}$ from the drainage channels. Groundwater-level observations were carried out once a week for one year.

\subsection{Soil sampling and analysis}

Soil samples were taken at depths of $0-50 \mathrm{~cm}, 50-100 \mathrm{~cm}$, and $100-150 \mathrm{~cm}$ using peat auger (Eijkelkamp model). Soil sampling was based on distances of $16 \mathrm{~m}, 100 \mathrm{~m}$, and $200 \mathrm{~m}$ from the drainage channel with three replications. Peat water content was determined by gravimetric analysis. Peat hydrophobicity was determined according to the functionalgroup approach of organic matter and analyzed using a Fourier-Transform Infrared (FTIR) spectrophotometer. Functional groups were identified based on the differences in infrared absorption intensity for each specific wavenumber in $\mathrm{cm}^{-1}$ (Artz et al., 2008; Krumins et al., 2012). The functional 
group's intensity was determined by peak area calculation based on each functional group's curve. The percentage of each functional group was calculated based on the spectra curve's total area.

\subsection{Data analysis}

Variation data were analyzed with standard error and illustrated using the SigmaPlot program. The distances from the drainage channel of the chambers and the PVC pipes did not differ between observation points. Therefore, $\mathrm{CO}_{2}$ flux and groundwater level during the observation period was the average value of the distance from the drainage channel.

\section{Results}

Carbon dioxide emissions occur due to aerobic decomposition of organic matter, which is influenced by soil and environmental factors. Soil moisture, or water content, is an environmental factor that plays a significant role in decomposition. Soil water content is influenced by peatforming material, peat maturity, and groundwater level. During the observation period, groundwater level fluctuation followed the same pattern for both the IRP and TMR (Figure 1). In April, the groundwater level increased and then began to decreased, reaching its lowest point in October 2015: $152.2 \pm$ $1.5 \mathrm{~cm}$ (IRP) and $133.6 \pm 1.0 \mathrm{~cm}$ (TMR) below ground level. The levels had increased again by the next observation period. This is supported by rainfall data (Figure 2), which indicates the dry season between July and October 2015. Rainfall is related to both groundwater level and river water level. In the rainy season, water is abundant, whereas, in the dry season, there is a water deficit, and the groundwater level is at its lowest, demanding water management.

Carbon dioxide flux for both plots fluctuated with high variability between the observation periods (Figure 3 ). The lowest $\mathrm{CO}_{2}$ concentration was observed in April, when the water level was close to the soil's surface. Moist soil can limit the diffusion of oxygen into the atmosphere (Sotta et al., 2004) and reduce the oxygen levels necessary for aerobic microbial activity (Moyano et al., 2013), decreasing the speed of the aerobic decomposition that produces $\mathrm{CO}_{2}$. Oxygen acts as an electron acceptor in the mineralization of soil organic matter (Keiluweit et al., 2016). For the IRP, the highest $\mathrm{CO}_{2}$ flux occurred in November 2015, (8191.2 $\pm 3370.2 \mathrm{mg} \mathrm{m}^{-2}$ day $\left.^{-1}\right)$; for the TMR, the highest $\mathrm{CO}_{2}$ flux occurred in October 2015 $\left(7503.6 \pm 2168.8 \mathrm{mg} \mathrm{m}^{-2}\right.$ day $\left.^{-1}\right)$. High $\mathrm{CO}_{2}$ flux might have been caused by reduced soil moisture due to low rainfall resulting in a significant groundwater-level decrease. Peat hydrophobicity can be assessed by analyzing certain functional groups using an FTIR spectrophotometer., which operates based on each functional group absorbing infrared light at a specific frequency (Krumins et al., 2012). Functional groups were identified as hydrophobic at peak absorptions of $1712 \mathrm{~cm}^{-1}$ ( $\mathrm{C}=\mathrm{C}$ bonds of esters, ethers, phenols, and benzene rings), $1627 \mathrm{~cm}^{-1}$ (esters, ethers, phenols, and $\mathrm{C}=\mathrm{C}$ groups in cyclic and benzene) and $1265 \mathrm{~cm}^{-1}$ (CO from esters, ethers, and phenols) (Artz et al., 2008; Matejkove \& Simon, 2012; Utami et al., 2009). Figure 4 shows the FTIR spectrogram for the peat from selected soil samples, the total width of the absorption area for hydrophobic peat having been obtained. The almost identical spectrum patterns at each observation point (peat depth $0-150 \mathrm{~cm}$ ) were outside the absorption area. For both IRP and TMR, the width of the absorption areas of hydrophobic peat decreased as soil depth increased (Figure 5). Besides the presence of specific functional groups, the factor determining whether the peat was hydrophobic was the water content, high water content is the main physical characteristic of peat. Peat water content is affected by peatforming material, degree of peat decomposition, and groundwater level. Peat water content was between 586.5 and $619.2 \%$ for IRP and 379.3 and $775.5 \%$ for TMR (Figure 6 ).

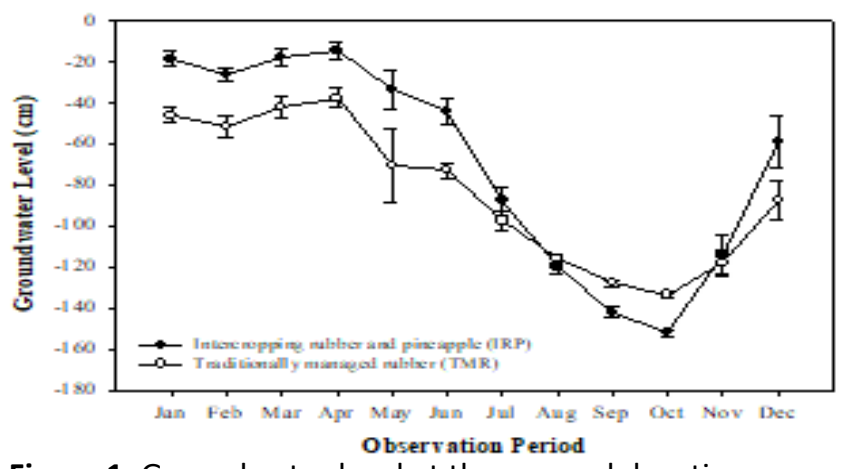

Figure 1. Groundwater level at the research location

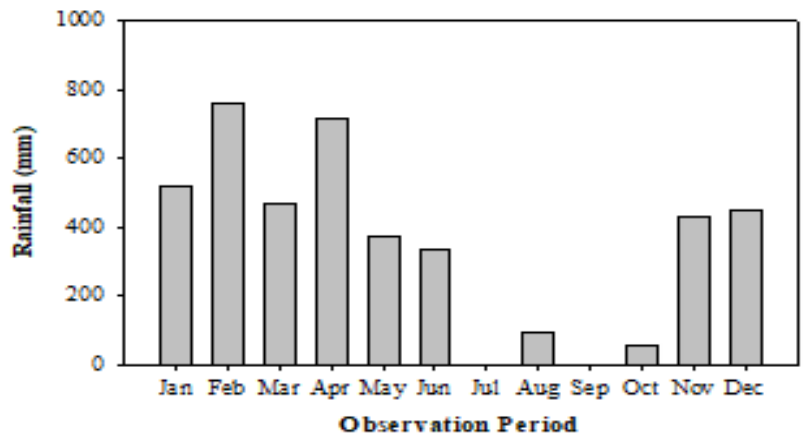

Figure 2. Monthly rainfall distribution during the study period

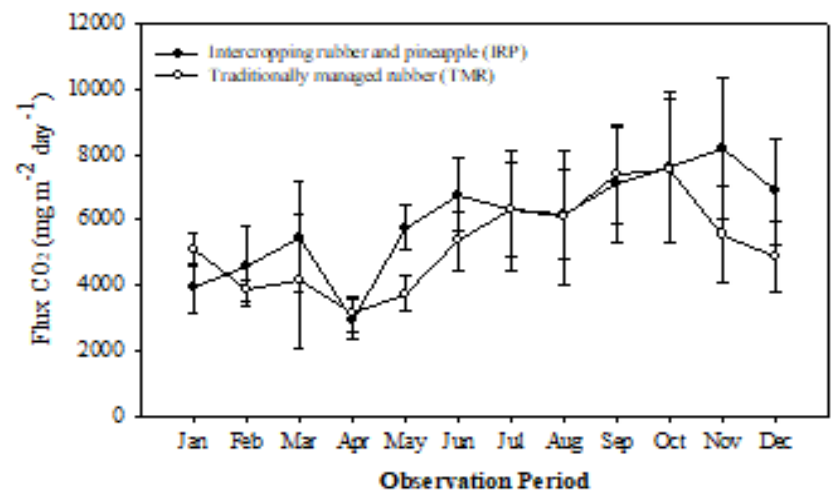

Figure 3. The dynamics of $\mathrm{CO}_{2}$ flux at the research location 

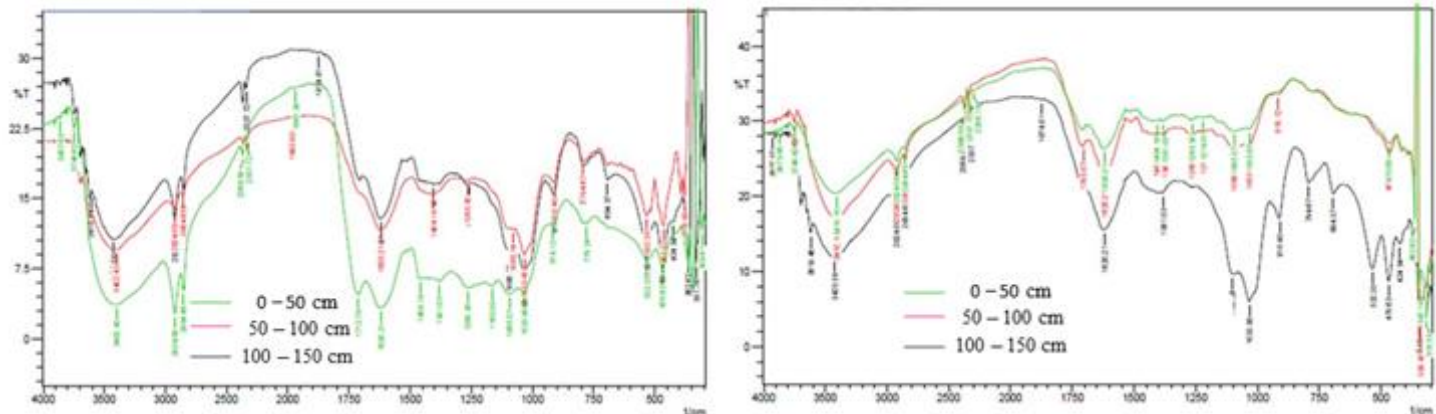

Rainy Season
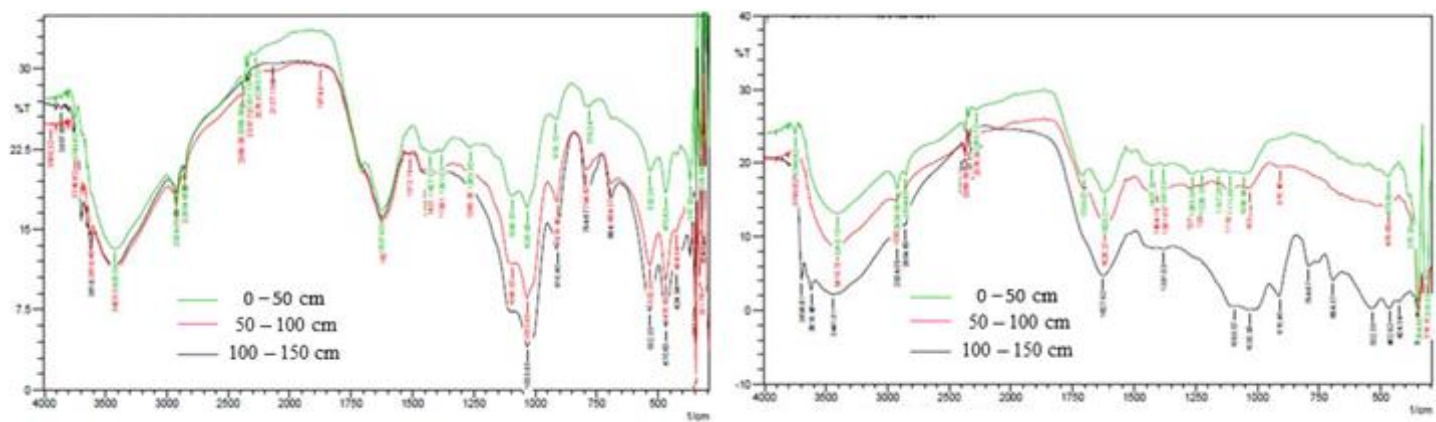

Intermediate
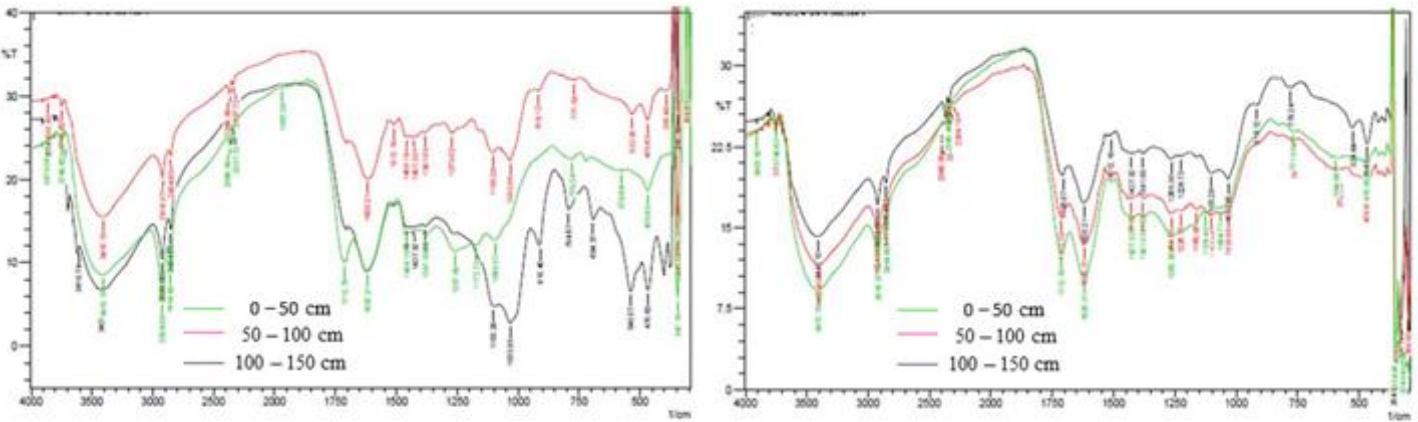

Dry Season

Intercropping rubber and pineapple

Traditionally managed rubber

Figure 4. Peat spectrogram FTIR for different observation points

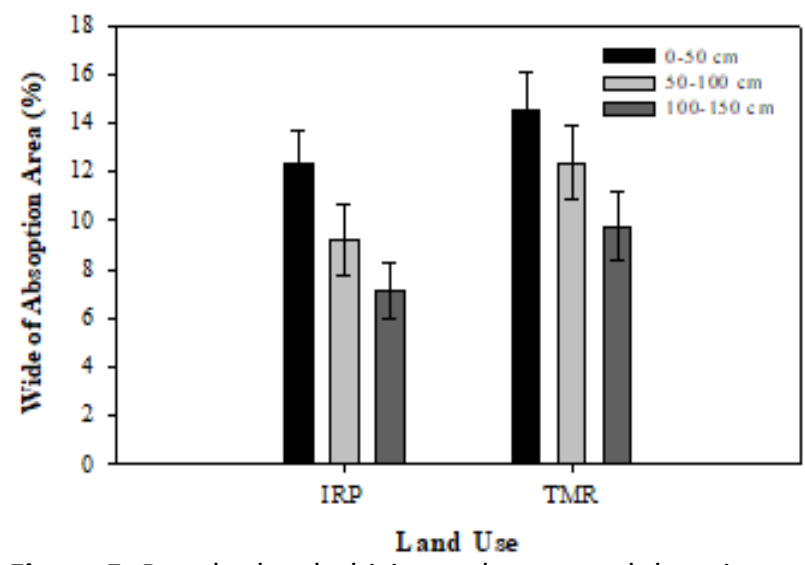

Figure 5. Peat hydrophobicity at the research location

\section{Discussion}

For peatlands in tropical areas such as Indonesia, soil formation is influenced by the anaerobic conditions with low temperatures that make decomposition slower than accumulation; in contrast, in temperate regions, organic matter accumulates due to low temperatures. These climate

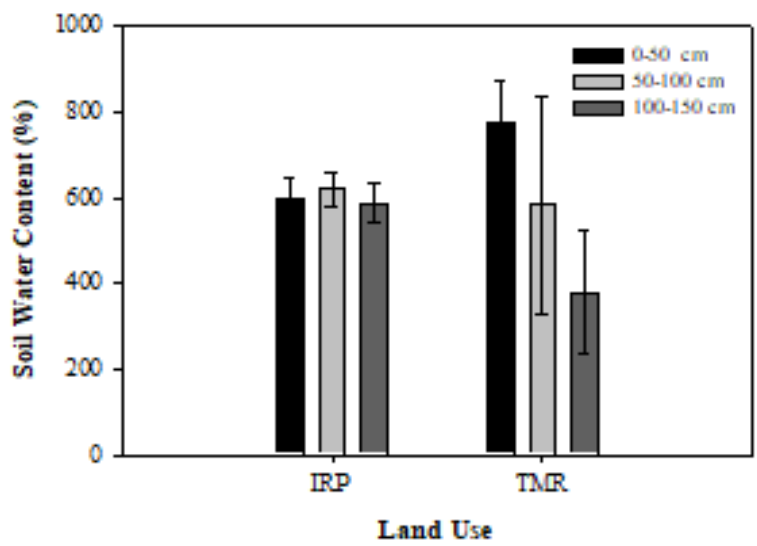

Figure 6. Peat water content at the research location

differences have a direct influence on the nature of peat swamps, especially hydrologically, in which regard peatlands are structured vertically and horizontally (Clymo, 1984). The vertical structure of peat consists of a saturated zone where there is no oxygen and organic matter decomposes anaerobically, known as the catotelmic zone; at the top of the catotelmic zone, there is an acrotelmic zone, which exists in 
aerobic conditions but can be saturated. The acrotelmcatotelm model suggests that most runoff and nutrient transfer production occurs in the upper peat, near or on the peat's surface.

In tidal peatlands, the acrotelmic zone varies substantially according to tides or rainfall, resulting in a process of wetting and drying that affects groundwater levels (Nurzakiah et al., 2014) and $\mathrm{CO}_{2}$ emissions (Wakhid et al., 2017). Larger acrotelmic zones allow a faster breakdown of organic matter into $\mathrm{CO}_{2}$ because of oxygen entering the peat. Seasonal changes affect the results of measurements of a region's $\mathrm{CO}_{2}$ emissions (Hirano et al., 2007). Several researchers have conducted regression and correlation analysis to assess $\mathrm{CO}_{2}$ emissions as a function of the groundwater table, observing positive correlations (Carlson et al., 2015; Ishikura et al., 2017; Wakhid et al., 2017). However, it is not always a linear relationship: groundwater-level decline is not always directly proportional to the increase in $\mathrm{CO}_{2}$ emissions because $\mathrm{CO}_{2}$ levels sometimes level off due to emissions decreasing because of decreasing groundwater levels. This can be caused by the surface of the peat irreversibly drying. A non-linear relationship between groundwater levels and $\mathrm{CO}_{2}$ emissions is caused by the presence of significant variations in soil properties (Makiranta et al., 2009). Additionally, $\mathrm{CO}_{2}$ emissions measurements are conducted in the field under uncontrolled conditions or in disturbed soil samples, where the original peat materials have changed (Lafleur et al., 2005; Nieveen et al., 2005). The critical factor in the regulation of $\mathrm{CO}_{2}$ emissions from peat is nutrient availability and the presence of oxygen on the soil surface.

In this study, groundwater level fluctuations were influenced by rainfall, the peak of the dry season occurring in October 2015 (Figure 1). The low rainfall in the dry season caused the groundwater level to reach $152.2 \pm 1.5 \mathrm{~cm}$ below the soil surface. However, decreased groundwater levels did not lead to a significant difference in $\mathrm{CO}_{2}$ flux (Figure 3 ). Carbon dioxide results from organic matter decomposition by microbes, which are strongly influenced by substrate availability (Andersen et al., 2013; Blessing et al., 2016; Kuzyakov \& Gavrichkova, 2010) and supported by environmental factors such as temperature and soil moisture so that decreased groundwater level does not always increase $\mathrm{CO}_{2}$ production. Soil moisture in the upper layer can be a better predictor of $\mathrm{CO}_{2}$ production than the groundwater level (Melling et al., 2013; Moyano et al., 2013). The inherent factor that determines peat moisture is the degree of peat decomposition associated with soil pores. At a certain limit, reduced soil moisture can cause a decrease in either or both of the carboxylic groups and $\mathrm{OH}$-phenolic, irreversibly drying the peat. This is a result of polar functional groups in the peat, such as carboxylic and hydroxyl, associating and interacting through hydrogen bonding that directs non-polar functional groups, such as ethyl, methyl, and aromatic compounds, towards the surface of organic colloid and hydrophobic peat.

The total absorption area of the hydrophobic functional group can be used to determine whether peat is hydrophobic (Figure 5). At a depth of $0-50 \mathrm{~cm}$, it has a larger absorption area. This indicates that peat on the surface layer $(0-50 \mathrm{~cm})$ is more susceptible to drought and fire if there are no water management measures. When groundwater levels decline significantly due to a drainage channel or reduced rainfall, hydrophilic peat can be lost due to fat, oil, or wax coverage, most of which come from the decomposition of organic matter. Therefore, maintaining soil moisture is very important. However, the mechanism that determines the decomposition response of organic matter to soil moisture is not well understood. This might be due to the difficulties of separating the effects of osmotic stress, solutes diffusion, and aeration and its relationship with moisture (Moyano et al., 2013).

For the TMR plot, the soil water content decreased with increasing soil depth. This might have been the result of mineral substances of varying thickness at depths of 100-150 $\mathrm{cm}$ causing a significant difference in soil water content compared to depths of $0-50 \mathrm{~cm}$. In contrast, for all observed soil depths of the IRP $(0-150 \mathrm{~cm})$, water content was similar within a small range (586.5-619.2\%). In general, both plots featured moisture content of more than $379 \%$. High water content in peat is related to the macropore structure formed as a result of partial degradation during the peat formation process. On the surface of the solid material of colloidal peat, water is bound through chemical bonds in polar groups, such as carboxylic groups, with components featuring heavy molecular weights. Colloidal water is absorbed by hydrophilic colloids and is responsible for peatland development and recession (Utami, 2010). One of the advantages of IRPmanaged rubber plantations is that $\mathrm{CO}_{2}$ absorption is higher than for unmanaged plants, as demonstrated by highly efficient photosynthesis and oxygen production, comparatively increasing the biomass-production abilities of plants. These conditions affect the microclimate: as the soil becomes more humid, it receives the shade of the vegetation above, indirectly leading to avoiding excess evaporation from the soil and the water table declining precipitously, especially in the dry season.

\section{Conclusion}

Carbon dioxide emissions were $21.78 \pm 5.44\left(\mathrm{Mg} \mathrm{ha}^{-1}\right.$ year $\left.^{-1}\right)$ for the IRP plot and $\left(19.15 \pm 5.18 \mathrm{Mg} \mathrm{ha}^{-1}\right)$ year ${ }^{-1}$ for the TMR plot. Peat hydrophobicity for both land-uses decreased with increasing soil depth. This indicates that peat on the surface layer $(0-50 \mathrm{~cm})$ is more vulnerable to drought and fires, especially if there is no water management.

It's difficult to eliminate $\mathrm{CO}_{2}$ from utilized peatlands; decomposition is a natural process that is also needed in the supply of nutrients to plants. Thus, sustainable peatland management should emphasize increasing productivity and lowering $\mathrm{CO}_{2}$ emission levels. Peatland water management is critical, an example of which is canal blocking to maintain soil moisture and minimize $\mathrm{CO}_{2}$ emissions.

\section{Declaration of Competing Interest}

The authors declare no competing financial or personal interests that may appear and influence the work reported in this paper. 


\section{References}

Agus, F., Marwanto, S., Dariah, A., Husen, E., Wigena, I. G. P., Maswar, \& Setyanto, P. (2013, November). Peat CO2 emissions from several land use types in Indonesia. MPOB International Palm Oil Congress (PIPOC).

Andersen, R., Chapman, S. J., \& Artz, R. R. E. (2013). Microbial communities in natural and disturbed peatlands: $A$ review. Soil Biology and Biochemistry, 57, 979-994. https://doi.org/10.1016/j.soilbio.2012.10.003

Artz, R. R. E., Chapman, S. J., Robertson, A. H. J., Potts, J. M., Laggoun-De'farge, F., Gogo, S., Comont, L., Disnar, J. R., \& Francez, A. J. (2008). FTIR spectroscopy can be used as a screening tool for organic matter quality in regenerating cutover peatlands. Soil Biology and Biochemistry, 40(2), 515-527. https://doi.org/10.1016/j.soilbio.2007.09.019.

Azri. (1999). Sifat kering tidak balik tanah gambut dari Jambi dan Kalimantan Tengah: analisis berdasarkan kadar air kritis, kemasaman total, gugus fungsional $\mathrm{COOH}$ dan $\mathrm{OH}$-fenolat. IPB University.

Blessing, C. H., Barthel, M., Gentsch, L., \& Buchmann, N. (2016). Strong coupling of shoot assimilation and soil respiration during drought and recovery periods in beech as indicated by natural abundance $\delta 13 \mathrm{C}$ measurements. Frontiers in Plant Science, 7(November), 1-12. https://doi.org/10.3389/fpls.2016.01710

Carlson, K. M., Goodman, L. K., \& May-Tobin, C. C. (2015). Modeling Relationships between Water Table Depth and Peat Soil Carbon Loss in Southeast Asian Plantations. Environmental Research Letters, 10(7), 112. https://doi.org/https://doi.org/10.1088/17489326/10/7/074006.

Chadwick, O. A., Kelly, E. F., Merritts, D. M., \& Amundson, R. G. (1994). Carbon dioxide consumption during soil development. Biogeochemistry, 24, 115-127. https://doi.org/10.1007/BF00003268

Clymo, R. (1984). The Limits to Peat Bog Growth. Philosophical Transactions of the Royal Society of London. Series B, Biological Sciences, 303, 605-654. https://doi.org/10.1098/rstb.1984.0002

Freeman, C., Ostle, N., \& Kang, H. (2001). An enzymic "latch" on a global carbon store - A shortage of oxygen locks up carbon in peatlands by restraining a single enzyme. Nature, 409, 149-149. https://doi.org/10.1038/35051650

Glatzel, S., Basiliko, N., \& Moore, T. (2004). Carbon dioxide and methane production potentials of peats from natural, harvested, and restored sites, eastern Quebec, Canada. Wetlands, 24, 261-267. https://doi.org/https://doi.org/10.1672/02775212(2004)024[0261:CDAMPP]2.0.CO;2.

Hirano, T., Segah, H., Harada, T., Limin, S., June, T., Hirata, R., \& Osaki, M. (2007). Carbon dioxide balance of a tropical peat swamp forest in Kalimantan, Indonesia. Global Change Biology, 13, 412-425. https://doi.org/https://doi.org/10.1111/j.13652486.2006.01301.x.

Hoag, R. S., \& Price, J. S. (1997). The effects of matrix diffusion on solute transport and retardation in undisturbed peat in laboratory columns. Journal of Contaminant Hydrology, 28, 193-205. https://doi.org/10.1016/S0169-7722(96)00085-X

Hooijer, A., Page, S., Canadell, J. G., Silvius, M., Kwadijk, J., Wosten, H., \& Jauhiainen, J. (2010). Current and future $\mathrm{CO} 2$ emissions from drained peatlands in Southeast Asia. Biogeosciences, 7, 1505-1514. https://doi.org/http://dx.doi.org/10.5194/bg-7-15052010.

Hoyos-santillan, J., Lomax, B. H., Large, D., Turner, B. L., Boom, A., Lopez, O. R., \& Sjogersten, S. (2016). Quality not quantity: organic matter composition controls of $\mathrm{CO} 2$ and $\mathrm{CH} 4$ fluxes in neotropical peat profiles. Soil Biology and Biochemistry, 103, 86-96. https://doi.org/. http://dx.doi.org/10.1016/j.soilbio.2016.08.017.

IAEA. (1992). Manual on Measurement of Methane and Nitrous Oxide Emission from Agricultural (TECHDOC674). International Atomic Energy Agency.

ICALRRD. (2019). Indonesian Peatland Map at Scale 1:50.000. Indonesian Center for Agricultural Land Resources Research and Development.

Ishikura, K., Yamada, H., Toma, Y., Takakai, F., Morishita, T., Darung, U., Limin, A., Limin, S. H., \& Hatano, R. (2017). Effect of Groundwater Level Fluctuation on Soil Respiration Rate of Tropical Peatland in Central Kalimantan, Indonesia. Soil Science and Plant Nutrition, 1(63), 1-13. https://doi.org/https://doi.org/10.1080/00380768.201 6.1244652

Keiluweit, M., Nico, P. S., Kleber, M., \& Fendorf, S. (2016). Are oxygen limitations under recognized regulators of organic carbon turnover in upland soils? Biogeochemistry, 127, 157-171. https://doi.org/10.1007/s10533-015-0180-6

Knorr, K. H., Lischeid, G., \& Blodau, C. (2009). Dynamics of redox processes in a minerotrophic fen exposed to a water table manipulation. Geoderma, 153, 379-392. https://doi.org/10.1016/j.geoderma.2009.08.023

Krumins, J., Klavins, M., Seglins, V., \& Kaup, E. (2012). Comparative study of peat composition by using FT-IR spectroscopy. Material Science and Applied Chemistry, 26, 106-114.

Kuzyakov, Y., \& Gavrichkova, O. (2010). Time lag between photosynthesis and carbon dioxide efflux from soil : a review of mechanisms and controls. Global Change Biology, 16, 3386-3406. https://doi.org/10.1111/j.1365-2486.2010.02179.x

Lafleur, P. M., Moore, T. R., Roulet, N. T., \& Frolking, S. (2005). Ecosystem respiration in a cool temperate bog depends on peat temperature but not water table. Ecosystems, 8(619-629). https://doi.org/10.1007/s10021-0030131-2

Laiho, R. (2006). Decomposition in peatlands: Reconciling seemingly contrasting results on the impacts of lowered water levels. Soil Biology \& Biochemistry, 38, 20112024.

https://doi.org/https://doi.org/10.1016/j.soilbio.2006. 02.017. 
Makiranta, P., Laiho, R., Fritze, H., Hytonen, J., Laine, J., \& Minkkinen, K. (2009). Indirect regulation of heterotrophic peat soil respiration by water level via microbial community structure and temperature sensitivity. Soil Biology \& Biochemistry, 41(4), 695-703. https://doi.org/10.1016/j.soilbio.2009.01.004

Masganti., Notohadikusumo, T., Maas, A., \& Radjagukguk, B. (2001). Hydrophobicity and its impact on chemical properties of peat. In J. Rieley \& S. Page (Eds.), Proceeding of the International Symposium on Tropical Peatlands (pp. 109-113).

Matejkove, S., \& Simon, T. (2012). Application of FTIR spectroscopy for evaluation of hydrophobic/hydrophilic organic components in arable soil. Plant, Soil, and Environment, 58(4), 192-195. https://www.researchgate.net/publication/279644946

Melling, L., Goh, K. J., Chaddy, A., \& Hatano, R. (2013). Soil CO2 fluxes from different ages of oil palm in tropical peatland of Sarawak, Malaysia as influenced by environmental and soil properties. Acta Horticulturae, 982, 25-35. https://doi.org/10.17660/ActaHortic.2013.982.2

Melling, L., \& Hensen, I. A. (2011). Greenhouse gas exchange of tropical peatlands-A review. Journal of Oil Palm Research, 23, 1087-1095.

Mezbahuddin, M., Grant, R. F., \& Hirano, T. (2014). Modeling Effects of Seasonal Variation in Water Table Depth on Net Ecosystem CO2 Exchange of a Tropical Peatland. Biogeosciences, 11(3), 577-599. https://doi.org/https://doi.org/10.5194/bg-11-5772014.

Michel, J. C., Riviere, L. M., \& Bellon-Fontaine, M. N. (2001). Measurement of the wettability of organic materials in relation to water content by the capillary rise method. European Journal of Soil Science, 52, 459-467. https://doi.org/10.1046/j.1365-2389.2001.00392.x

Moyano, F. E., Manzoni, S., \& Chenu, C. (2013). Responses of soil heterotrophic respiration to moisture availability: An exploration of processes and models. Soil Biology and Biochemistry, 59, 72-85. https://doi.org/10.1016/j.soilbio.2013.01.002

Nieveen, J. P., Campbell, D. I., Schipper, L. A., \& Blair, I. . J. (2005). Carbon exchange of grazed pasture on a drained peat soil. Global Change Biology, 11(4), 607-618. https://doi.org/10.1111/j.1365-2486.2005.00929.x

Nurzakiah, S., Sabiham, S., Nugroho, B., \& Nursyamsi, D. (2014). Estimation of the potential carbon emission from acrotelmic and catotelmic peats. Journal of Tropical Soil, 19, 91-99. https://doi.org/https://doi.org/10.5400/jts.2014.v19i2
.81-89.

Rezanezhad, F., Price, J. S., Quinton, W. L., Lennartz, B., Milojevic, T., \& Cappellen, P. V. (2016). Structure of peat soils and implications for water storage, flow and solute transport: A review update for geochemists. Chemical Geology, 429, 75-84. https://doi.org/10.1016/j.chemgeo.2016.03.010

Rezanezhad, F., Quinton, W. L., Price, J. S., Elrick, D., Elliot, T., \& Shook, K. R. (2010). Influence of pore size and geometry on peat unsaturated hydraulic conductivity computed from 3D computed tomography image analysis. HYDROLOGICAL PROCESSES, 24, 2983-2994. https://doi.org/10.1002/hyp.7709

Rieley, J., \& Page, S. (2016). Tropical Peatland of the World. In M. Osaki \& N. Tsuji (Eds.), Tropical Peatland Ecosystems (1st ed., pp. 3-32). Springer Japan. https://doi.org/10.1007/978-4-431-55681-7

Sollins, P., Homann, P., \& Caldwell, B. A. (1996). Stabilization and destabilization of soil organic matter: mechanisms and controls. Geoderma, 74, 65-105. https://doi.org/10.1016/s0016-7061(96)00036-5

Sotta, E. D., Meir, P., Malhi, Y., Nobre, A. D., \& Hodnett, M. (2004). Soil CO2 efflux in a tropical forest in the central Amazon. Global Change Biology, 10(5), 601-617. https://doi.org/https://doi.org/10.1111/j.15298817.2003.00761.x.

Sundari, S., Hirano, T., Yamada, H., Kusin, K., \& Limin, S. (2012). Effect of groundwater level on soil respiration in tropical peat swamp forests. Journal of Agricultural Meteorology, 68(2), 121-134.

Utami, S. N. H., Maas, A., Radjaguguk, B., \& Purwanto, B. H. (2009). Sifat fisik, kimia, dan FTIR spektrofotometri gambut hidrofobik Kalimantan Tengah. Jurnal Tanah Tropika, 14(2), 159-166.

Valat, B., Jouany, C., \& Riviere, L. M. (1991). Characterization of the wetting properties of air-dried peats and composts. Soil Science, 152(2), 100-107.

Wakhid, N., Hirano, T., Okimoto, Y., Nurzakiah, S., \& Nursyamsi, D. (2017). Soil Carbon Dioxide Emissions from a Rubber Plantation on Tropical Peat. Science of the Total Environment, 581-582(857-865). https://doi.org/https://doi.org/10.1016/j.scitotenv.20 17.01.035.

Winarna. (2015). Pengaruh kedalaman muka air tanah dan dosis terak baja terhadap hidrofobisitas tanah gambut, emisi karbon, dan produksi kelapa sawit. IPB University. 